(c) American Dairy Science Association, 2006.

\title{
Endoscopic Examination and Tissue Sampling of the Bovine Teat and Udder Cistern
}

\author{
F. Vangroenweghe, ${ }^{*}$ W. Van Den Broeck, $†$ A. De Ketelaere, ${ }^{*}$ H. van Bree,‡ \\ L. Duchateau, ${ }^{*}$ and C. Burvenich ${ }^{1 *}$ \\ *Department of Physiology-Biometrics, Milk Secretion and Mastitis Research Center, \\ †Department of Morphology, and \\ fDepartment of Medical Imaging of Domestic Animals, Faculty of Veterinary Medicine, Ghent University, \\ Salisburylaan 1339820 Merelbeke, Belgium
}

\begin{abstract}
The aim of this study was to evaluate the application of an endoscopic technique to investigate the teat and udder cisterns of the bovine mammary gland, and to biopsy tissues within the cisterns. An anesthetic protocol for application in standing animals was designed, using a combination of general and local anesthesia. Individual quarter milk production (QMP), quarter somatic cell count (SCC), and occurrence of new intramammary infection were assessed after application of the technique, and possible applications for biopsies collected were investigated. Bovine teat and gland cistern lining could be visualized and small biopsy samples could be collected. The collected biopsy samples were successfully used in histological-histopathological examination and PCR analysis. To study the impact of endoscopy on QMP, milk SCC, and bacteriology, endoscopic examination of 12 low SCC $(<200,000$ cells/ $\mathrm{mL}$ ) quarters was performed in 8 different first- and second-lactation cows. Immediately following endoscopy, 8 quarters received antibiotic treatment, whereas 4 quarters remained untreated. During a 15$\mathrm{d}$ follow-up, no new intramammary infection could be observed in the endoscopically treated quarters. For QMP, no significant interaction between time and treatment could be observed throughout the 15-d follow-up period. Quarter SCC did not differ among treatments (control, endoscopy with antibiotics, and endoscopy without antibiotics). In conclusion, the endoscopic technique is suitable for examination and tissue biopsy collection of the bovine mammary gland cisterns without major interference with QMP and quarter SCC.
\end{abstract}

Key words: bovine mammary gland, cistern, endoscopy, histology

Received July 14, 2005.

Accepted November 28, 2005.

${ }^{1}$ Corresponding author: christian.burvenich@UGent.be

\section{INTRODUCTION}

Diagnosis and treatment of teat injuries and stenosis has been performed for several decades (Roine, 1975). Major problems associated with teat injuries and stenosis are compromised milk flow, poor milkability, abnormal milk, presence of pathogens, and greater risk for mastitis in the affected quarters (Querengasser et al., 2002). Besides a good anamnesis and a thorough clinical examination involving palpation of the affected glands, various techniques, such as radiography, ultrasonography (Stocker et al., 1989), and theloscopy (Tulleners and Hamir, 1990; Medl et al., 1994; John et al., 1998; Seeh and Hospes, 1998; Hirsbrunner and Steiner, 1999; Hirsbrunner et al., 2001), have been introduced for diagnosis and subsequent treatment of teat problems. In contrast to the classical surgical approach, theloscopy using an endoscope has been proven quicker, less invasive, nontraumatic, and free of major postoperative complications, such as hemorrhages, inefficient wound healing, and mastitis (Tulleners and Hamir, 1990).

Most of the currently applied techniques for mammary gland endoscopy have curative purposes and focus on treatment of teat injuries and stenosis in highyielding dairy cows (John et al., 1998; Hirsbrunner and Steiner, 1999; Hirsbrunner et al., 2001). The development of an in vitro bovine mammary teat and ductal epithelial cell culture technique for pathogen adhesion (Cifrian et al., 1994), and neutrophil diapedesis studies during health and mastitis (Smits et al., $1996 ; 1998 ; 1999)$ have demonstrated that freshly collected mammary tissue samples are essential for longitudinal studies. Initially, tissue samples were prelevated from bovine udders at necropsy (Cifrian et al., 1994; Plath et al., 1997). A number of researchers, using surgical prelevation techniques (Knight et al., 1992; Farr et al., 1996; Schmitz et al., 2004), have obtained large tissue samples $\left(1 \mathrm{~cm}^{3}\right.$ or 30 to $\left.60 \mathrm{mg}\right)$. Postinvasive complications, however, were multiple, such as blood clots in milk, fistula formation, and mastitis. Therefore, an endoscopic approach through the 
ductus papillaris may be a more suitable alternative for the collection of fresh biopsies of the lower parts (i.e., lactiferous cistern) of the mammary gland (Tulleners and Hamir, 1990; Persson et al., 1992; Shakespeare, 1998). Using an endoscopic technique, follow up of macroscopic lesions occurring during experimentally induced mastitis could be of interest. Further, biopsy samples collected before, during, and after experimentally induced mastitis could be used for histological, histopathological and immunohistochemical examination.

The aim of the present study was to evaluate the application of an endoscopic technique to investigate the teat and udder cisterns of the bovine mammary gland, and biopsy tissues within the cisterns. Quarter milk production (QMP), quarter SCC, and occurrence of new IMI were evaluated after application of the technique, and possible applications for biopsies collected were investigated.

\section{MATERIALS AND METHODS}

\section{Experimental Animals and Housing}

The study was approved by the Ethical Committee of the Faculty of Veterinary Medicine (Ghent University, Belgium). Midlactating cows in their first $(n=4)$ or second $(\mathrm{n}=4)$ lactations were selected on the basis of 3 consecutive bacteriologically negative examinations and a quarter milk SCC below 200,000 cells $/ \mathrm{mL}$. Cows were housed in a tie-stall barn at Ghent University. They were milked twice daily at 0800 and $1630 \mathrm{~h}$. Average daily milk production was $10 \mathrm{~L}$. The ration consisted of hay and water ad libitum and concentrates were distributed according to milk production.

\section{Endoscopic Procedure}

Before endoscopic examination, the cows were milked following intravenous administration of 0.77 IU of oxytocin (10 IU/mL, VMD, Arendonck, Belgium) into a jugular vein to obtain a maximal emptying of the mammary gland. The cows were restrained in a head catch, and a rope secured the hind and forelegs. The cow was sedated through epidural injection with a combination of xylazine and morphine (George, 2003). This anesthetic protocol can only be performed on nonfood-producing (experimental) animals in the European Union, because no maximum residue limit is available for morphine in lactating dairy cows. The teat end was disinfected with $70 \%$ ethanol- $0.5 \%$ chlorhexidin. Following disinfection, a sterile teat cannula (7 cm $\times 2 \mathrm{~mm}, \mathrm{MeVeMat}$, Deinze, Belgium) was inserted through the ductus papillaris to remove the remaining milk. Twenty milliliters of procaine (pro- caine hydrochloride $2 \%$; VMD) combined with an equal volume of sterile pyrogen-free saline solution $(0.9 \%$ $\mathrm{NaCl}$; Laboratoire Aguettant, Lyon, France) was infused into the teat and udder cistern, and the lower part of the mammary gland was massaged for $30 \mathrm{~s}$ to obtain a good distribution of the infused anesthetic product throughout the cisterns.

The method for teat and cisternal endoscopy in the bovine udder described by Shakespeare (1998) was adapted. Use of filtered air inflation to increase visualization and performance of a stab incision for biopsy collection were omitted. Briefly, the endoscope (cystourethroscope compact $8616.411,14 \mathrm{~cm} \times 3.0 \mathrm{~mm}$ outside diameter, visualization angle $0^{\circ}$; Endoscopie Richard Wolf, Drongen, Belgium), equipped with a biopsy channel, was connected to a video camera (Strycker Vision, Sunnyvale, NY). During introduction and throughout the endoscopic procedure, the mammary quarter was continuously rinsed with sterile, pyrogenfree saline solution to obtain better visualization of the internal structures. A flexible biopsy forceps (829.03, 23.5 cm, 5 charr.; Endoscopie Richard Wolf) was used for tissue sampling.

\section{Visualization of the Teat and Udder Cistern and Biopsy Sampling}

Using a digital camera (Sony Digital Handycam TVR25E, Sony, Tokyo, Japan), digital pictures of the teat-gland cistern and lactiferous duct structures were captured throughout the entire explorative session (Figure 1). Small tissue biopsies $\left(1 \mathrm{~mm}^{3}\right)$ were collected at different locations throughout the mammary gland using the flexible biopsy forceps. After collection, the tissue biopsies for histological examination (paraffin sections) were transferred into PBS containing $4 \%$ formaldehyde and fixed for 12 to $24 \mathrm{~h}$. Tissue biopsies for mRNA PCR analyses were frozen separately in RNAlater (Sigma-Aldrich, St. Louis, MO). Biopsies were further processed for histological and histopathological examination. Each biopsy sample could only be used in a single application.

\section{General Histological Procedures}

Formaldehyde-fixed mammary tissue biopsies were dehydrated through graded series $(50,70,80,94$, and $100 \%$ ) of ethanol and embedded in paraffin. Sections (7 $\mu \mathrm{m}$ thick) were cut, mounted on 3-aminopropyltriethoxysilane-coated slides (Sigma, St. Louis, MO), dried for $1 \mathrm{~h}$ at $60^{\circ} \mathrm{C}$ on a hot plate, and dried overnight at $37^{\circ} \mathrm{C}$. Subsequently, the sections were deparaffinized in 2 changes of xylene, rehydrated through graded series of ethanol, and stained with hematoxylin and 


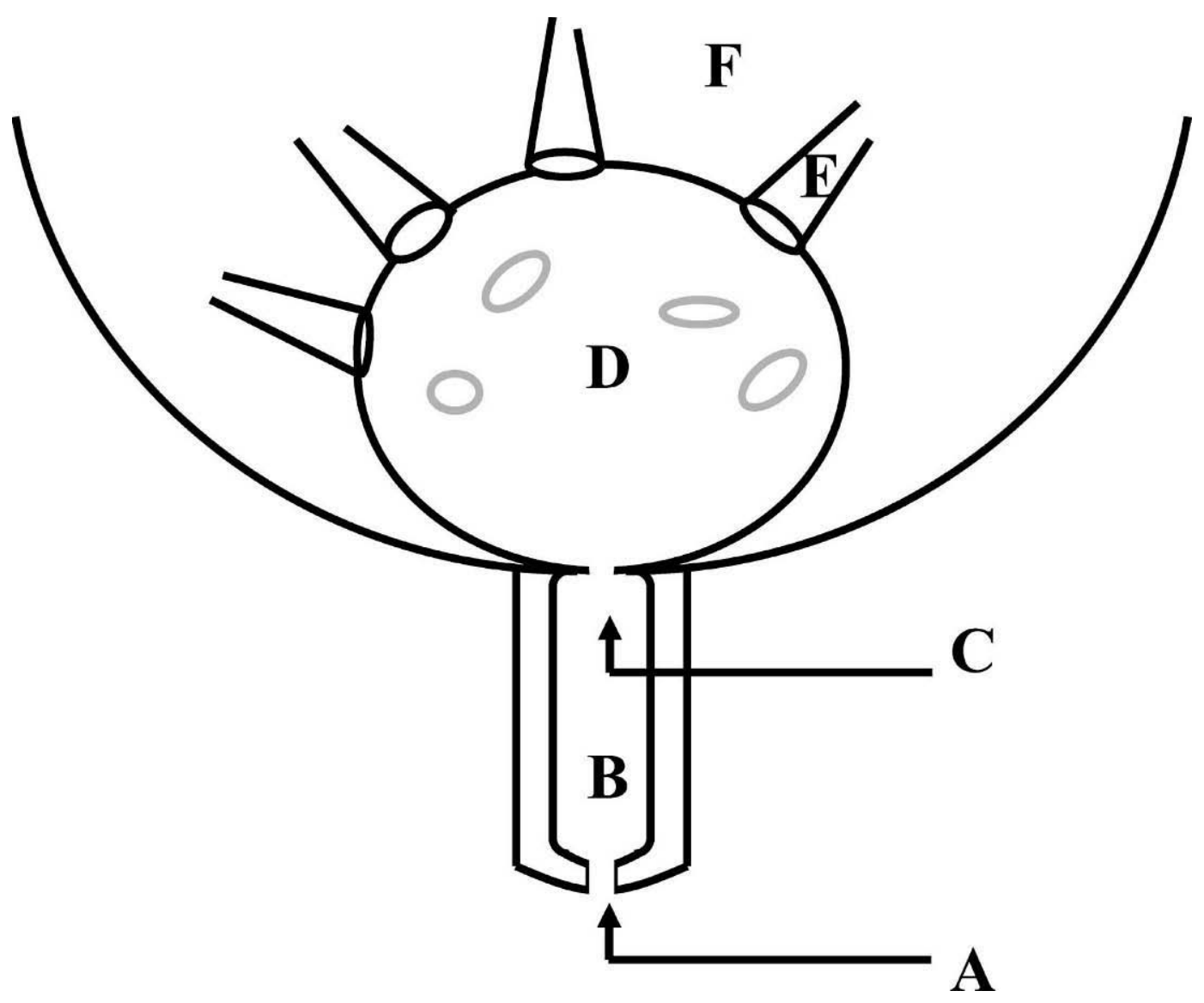

Figure 1. Schematic view of the anatomical structures of the lower part of the bovine mammary gland. $A=$ teat canal, $B=$ teat cistern, $\mathrm{C}=$ plica annularis mucosae (Fürstenberg rosette), $\mathrm{D}=$ gland cistern (cistern lactiferous), $\mathrm{E}=$ large milk duct, and $\mathrm{F}=$ alveolar parenchyma.

eosin for 10 min. Following staining, slides were washed in water for 5 to $10 \mathrm{~min}$, dehydrated, and incubated in 2 changes of xylene. Cover slips were added using DPX mounting medium (VWR International, Leuven, Belgium).

\section{Total RNA Extraction and mRNA Analysis}

Small pieces $\left(1 \mathrm{~mm}^{3}\right)$ of cisternal mammary tissue, frozen separately in RNAlater (Sigma-Aldrich), were thawed. Total RNA was isolated from these biopsies using total RNA isolation reagent (Abgene, Epsom, UK), followed by DNA digestion using RQ1 RNase-free DNase (Promega, Mannheim, Germany) according to the manufacturer's protocol. To exclude contamination with genomic DNA, a glyceraldehyde-3-phosphate dehydrogenase (GAPDH) fragment spanning several exons was amplified by PCR (results not shown). The DNase-treated RNA was used for generating singlestranded cDNA using the iScript cDNA synthesis kit (BioRad, Hercules, CA) according to the manufacturer's protocol.
The obtained cDNA served as template for a PCR using primers specific for the bovine GAPDH transcript (119 bp). The PCR reaction included 25 repetitions of the following cycle: a denaturation step at $95^{\circ} \mathrm{C}$ for $1 \mathrm{~min}$, an annealing step at $60^{\circ} \mathrm{C}$ for $30 \mathrm{~s}$, and an elongation step at $72^{\circ} \mathrm{C}$ for $30 \mathrm{~s}$. A negative control using water instead of cDNA was used to exclude contamination.

\section{Postinvasive Follow-Up of the Explored Glands}

After removal of the endoscope, the individual udder quarter was emptied by hand milking and an antibiotic suspension (lincomycin; Lincocin intramammary tube, Pfizer Animal Health, Sandwich, UK) was administered into the teat cistern. Eight out of 12 quarters were treated with the intramammary antibiotic suspension (endoscopy + antibiotics), whereas 4 did not receive any additional treatment (endoscopy). Of the 8 cows, 4 cows (first lactation, $\mathrm{n}=2$; second lactation, $\mathrm{n}=2$ ) were explored in 2 quarters; the other cows were only explored in a single quarter. Endoscopic 
exploration included visual examination and multiple tissue biopsy sampling in all examined quarters. Antibiotic treatment was evenly distributed between both lactation groups.

From $2 \mathrm{~d}$ before until $15 \mathrm{~d}$ after the intramammary endoscopic exploration, foremilk samples $(1 \mathrm{~mL})$ were collected daily before morning milking for bacteriological examination for major mastitis pathogens. Furthermore, milk samples were collected for evaluation of presence of blood $(10 \mathrm{~mL})$ and for the analysis of SCC $(50 \mathrm{~mL})$ using a fluoro-opto-electronic method (Fossomatic 400, Foss Electric, Hillerød, Denmark). All milk samples were collected according to International Dairy Federation standards. Serum albumin concentration was quantified in the endoscopy-treated quarters (endoscopy vs. endoscopy + antibiotics) using a radial immunodiffusion test (Vangroenweghe et al., 2004; 2005). Quarter milk production was quantified using a quarter milking device (Packo and Fullwood, Zedelgem, Belgium). Daily QMP was calculated as the total milk production of the evening milking and the subsequent morning milking. Presence of blood in the milk samples was evaluated through visual inspection of the pellet following centrifugation $(1,000 \times g, 10$ $\min )$.

To control aseptic conditions of the technique, rinsing fluid samples (8 per explored quarter, length of each rinse approximately $60 \mathrm{~s}$ ) for bacteriological examination were collected throughout the endoscopic exploration. Following collection, $1 \mathrm{~mL}$ of the rinsing fluid was plated out onto sheep blood agar, incubated at $37^{\circ} \mathrm{C}$ for $24 \mathrm{~h}$, and subsequently all colonies on the plate were counted.

\section{Statistical Analyses}

Quarter milk production, serum albumin concentration, and SCC (log transformed for assumed normal distribution) were compared among the 3 treatments by a mixed model with cow as random effect and time, treatment, and their interaction as categorical fixed effects. The 3 treatments were compared pairwise at a global significance level of 5\% using Tukey's multiple comparisons adjustment technique.

\section{RESULTS}

\section{Visualization of the Teat and Udder Cistern and Tissue Biopsy Sampling}

Introduction of the endoscope through the ductus papillaris into the teat canal was successful in all of the examined quarters. No substantial differences in penetrability of the teat canal were observed between quarters of first- and second-lactation cows (results not shown).

Endoscopy revealed a clear view of all parts of the lactiferous cistern, such as the teat cistern (Figure $2 \mathrm{a}$ ) and the plica annularis mucosae (Figure 2b). Teat contraction and relaxation could be observed during endoscopic examination of the teat cistern. In the gland cistern, multiple lactiferous ducts could be observed (Figure 2c). With the endoscope's full length it was possible to enter a large milk duct to visualize the upper system branching into small lactiferous ducts deeper in the mammary gland parenchyma (Figure $2 \mathrm{~d})$.

Tissue biopsy samples could be collected easily from different locations in the gland cisterns without apparent bleeding or lesions. Sample volume obtained with this endoscopic technique was sufficient for use in histological and histopathological examinations and PCR analysis. Tissue samples could be obtained with a minimum of tissue damage or crushing, which resulted in good recognition of microscopic structures during histological examination. Tissue biopsy samples were collected at more than 2 different locations from each of the endoscopically examined quarters $(n=12)$ of the 8 cows in the study.

\section{Histological Examination}

Observation of the paraffin sections (Figure $3 \mathrm{a}$ and $3 \mathrm{~b})$ shows that the morphology remains intact after biopsy sampling. In the samples of both the teat cistern (Figure 3a) and the transition zone between teat and gland cistern (Figure 3b), the 2-layered cuboidal epithelium and connective tissue fibers could easily be recognized, as well as blood vessels in the loose connective tissue beneath the epithelium.

\section{Analysis of mRNA}

Total RNA extraction and subsequent mRNA analysis was successful in biopsy samples collected from 7 of 8 cows. Although the exact amount of extracted total RNA could not be measured because of its low concentration, the obtained RNA could be used for reverse transcription and PCR analysis. Following gel electrophoresis and ethidium-bromide staining, clear bands at $119 \mathrm{bp}$, representing the GAPDH transcript, could be visualized (Figure 4).

\section{Evaluation of Postinvasive Complications}

All rinsing fluid samples collected during endoscopy were negative for the presence of bacteria, which indicates that the endoscopic procedure for the collection 

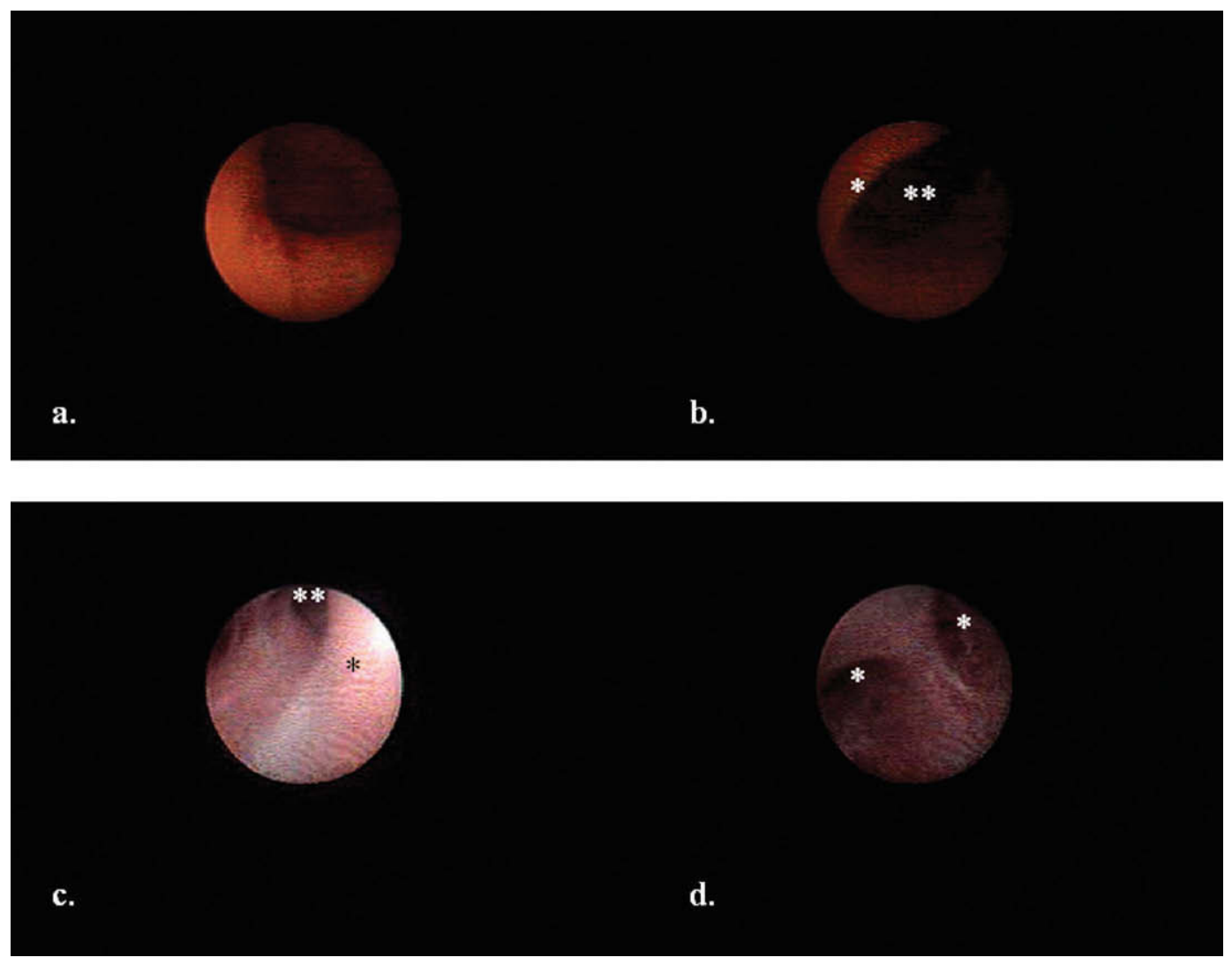

Figure 2. Endoscopic image from a) the teat cistern epithelial lining; b) region of the plica annularis mucosae (Fürstenberg rosette *), within the front the teat cistern, evolving into a ring-shaped narrowing and continuing into the udder cistern (central black part, **); c) udder cistern-lactiferous duct region with a close-up aspect of udder cistern lining (*) with the lactiferous ducts (**); and d) lactiferous duct with different smaller ducts $(*)$ branching deeper into the udder parenchyma.

of tissue biopsy samples was carried out under acceptable aseptic conditions. Cows were free of major mastitis pathogens before the start of the experiment and all foremilk samples collected after the endoscopic exploration remained bacteriologically negative. No blood could be detected in the milk originating from
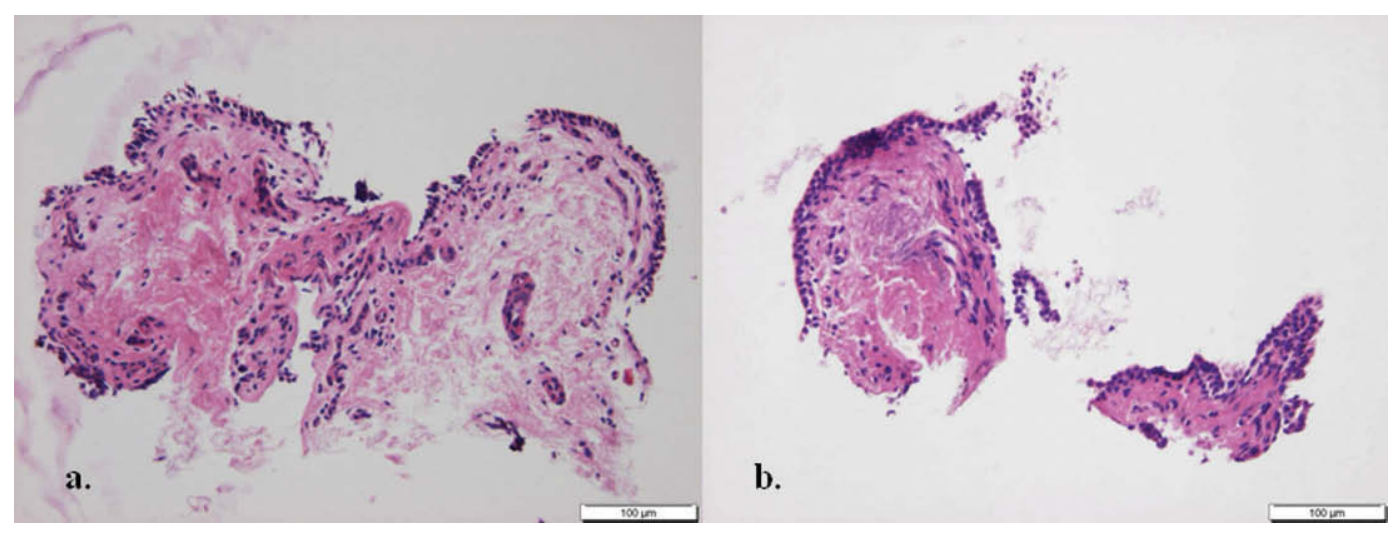

Figure 3. Light microscopic images showing the morphology of biopsy samples: a) biopsy sample originating from the teat cistern; and b) biopsy sample taken at the transition zone (region of Fürstenberg rosette) between teat and gland cistern. The 2-layered cuboidal epithelium can easily be recognized, besides other cell types, connective tissue fibers, and blood vessels in the loose connective tissue beneath the epithelium $($ bar $=100 \mu \mathrm{m})$. 


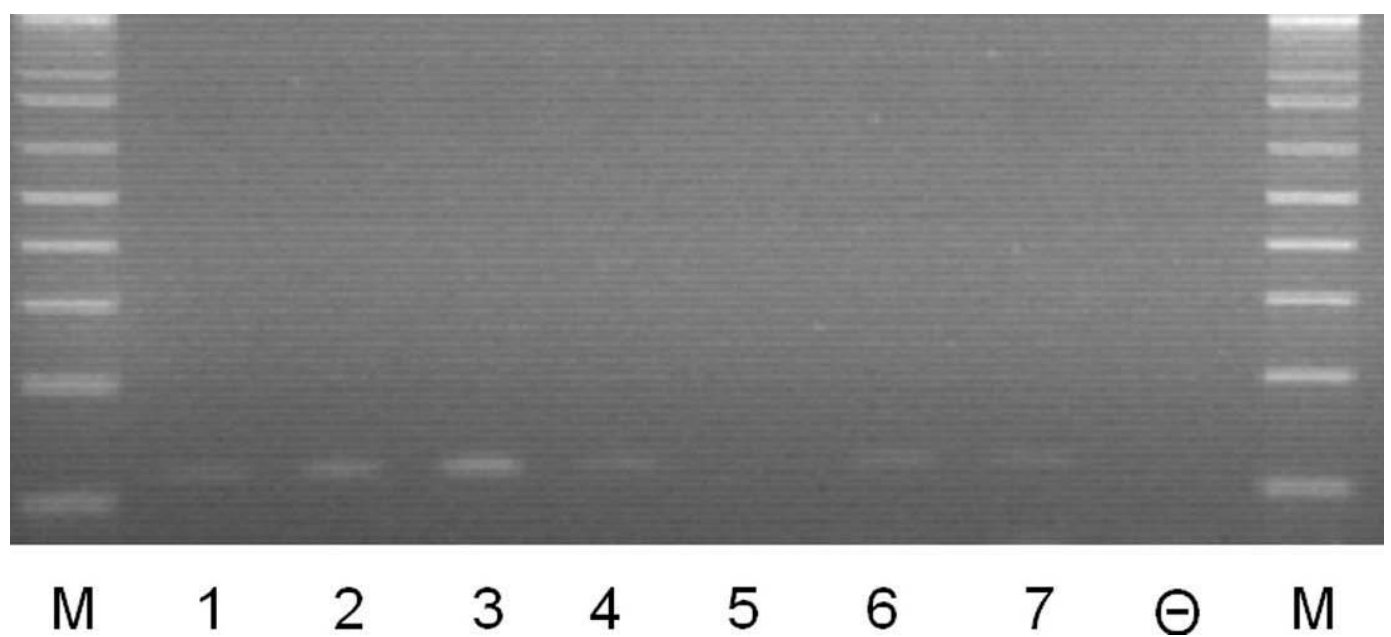

Figure 4. Agarose gel following electrophoresis and ethidium bromide staining, revealing a glyceraldehyde-3-phosphate dehydrogenase fragment (119 bp) amplified from cDNA, originating from total RNA extracted out of endoscopically collected bovine mammary gland biopsy samples. Cow identification: 1 to $7, \ominus=$ negative control, $M=b p$ marker.

the treated quarters following endoscopy (results not shown).

Quarter milk production was smallest on the day of endoscopy mainly because the evening milking following endoscopic exploration of the glands was omitted. Following endoscopy, QMP rapidly recovered to preendoscopy levels (Figure 5). No significant interaction between time and treatment could be detected for QMP throughout the entire study period. On the day of endoscopy, LogSCC varied between 4.16 and 4.62 per $\mathrm{mL}$ of milk, and did not differ among treatments. Following endoscopy, no effect of treatment on SCC could be observed, although a slight numerical increase in SCC could be observed, reaching a maximum $2 \mathrm{~d}$ after endoscopy (Figure 6). Serum albumin concentration in the treated glands increased $(P<0.01)$ on $d 2$ after endoscopy in both treated groups. Significant differences between endoscopically treated groups were, however, not present. At d 4 after endoscopy, serum albumin concentrations returned to normal concentrations (results not shown).

\section{DISCUSSION}

The presented endoscopic technique, approaching the bovine mammary gland through the ductus papillaris, allowed exploration of the bovine mammary teat and gland cistern without pronounced postexplorative complications. No abnormalities in milk composition, such as blood clots, flakes, or increased SCC, could be observed following endoscopic exploration of the bovine mammary gland. Analysis of quarter SCC revealed only a slight numerical increase in the days following endoscopy. This increase could be expected because of the intracisternal manipulation and biopsy sampling. It does, however, not compromise the utility of the above described endoscopic procedure. Quarter milk production was smallest on the day of endoscopy in all quarters because of skipping the evening milking following the endoscopic exploration of the mammary glands. Rapid recovery of QMP to pre-endoscopic production levels was observed in the days following endoscopy. Postexplorative administration of intramammary antibiotics did not affect QMP or quarter SCC. New IMI were not observed in any cow after endoscopic treatments.

Although all quarters used in this study were lactating, excellent visualization of the internal structures of the teat and udder cistern was obtained by rinsing with sterile, pyrogen-free saline solution. Although continuous milk flow of the large milk ducts into the gland cistern of the lactating udder may sometimes disturb visibility, the removal of residual alveolar milk through intravenous oxytocin administration before endoscopy resolved most of these visibility problems. Interference of milk descending from the alveoli and the gland cistern into the teat cistern was described previously for the bovine and was the main reason for surgical separation of teat and gland cistern in previous studies (Persson and Åstrom, 1989; Persson and Hallén Sandgren, 1992; Persson et al., 1992, 1993). In these studies, separation was performed to eliminate disturbing effects from mammary gland secretions in the teat cistern during experimental polymorphonuclear leukocyte (PMN) diapedesis studies (Persson and Åstrom, 1989; Persson and Hallén Sand- 


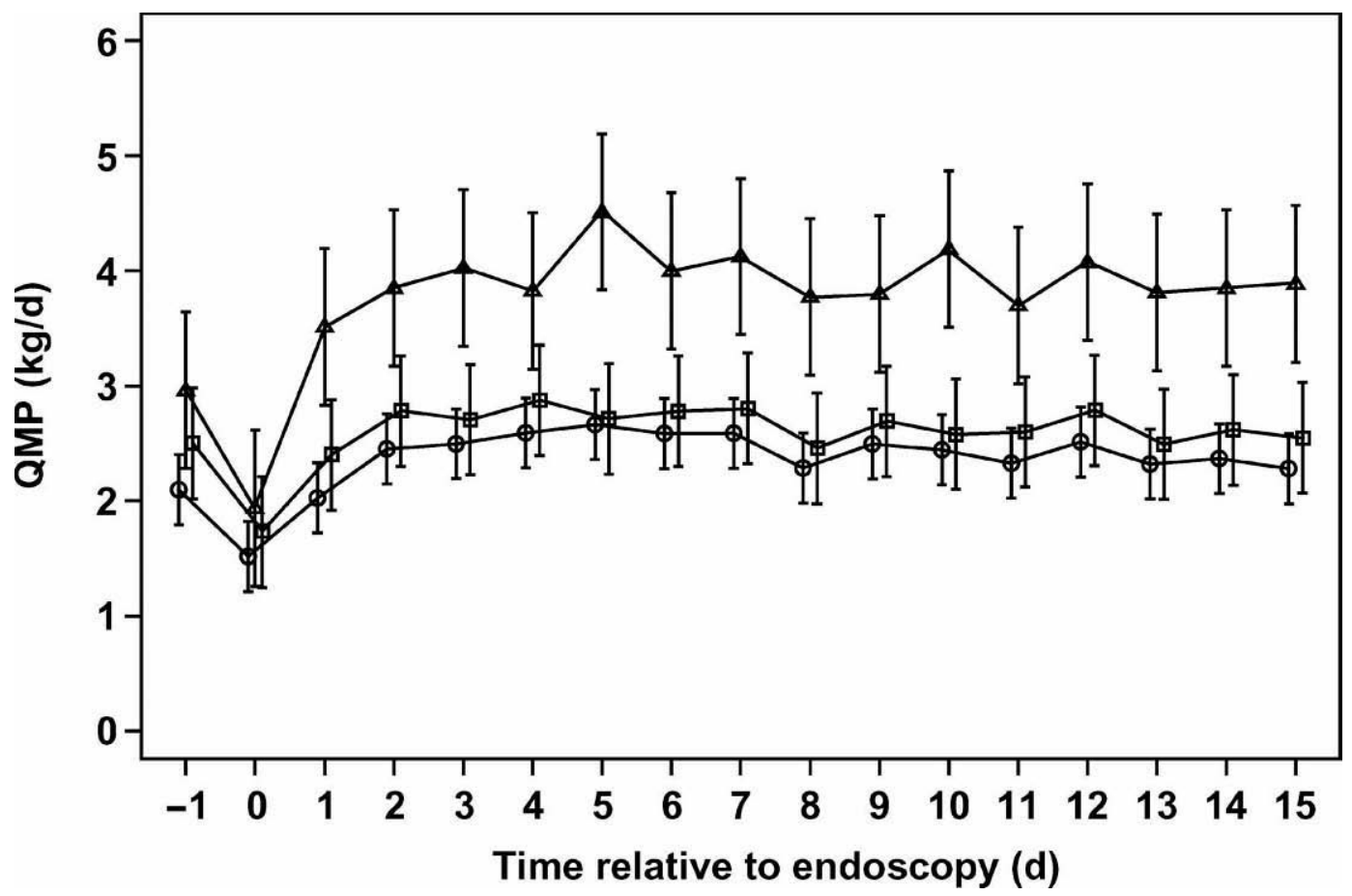

Figure 5. Mean \pm SEM quarter milk production (QMP; kg/d) before and after endoscopic exploration of bovine mammary gland. All endoscopically treated quarters were visually explored and multiple tissue biopsy samples were collected. Day 0 represents the day of endoscopy; $O=$ control quarters $(n=20), \Delta=$ endoscopy without antibiotic treatment $(n=4)$, and $\square=$ endoscopy + antibiotics $(n=8)$.

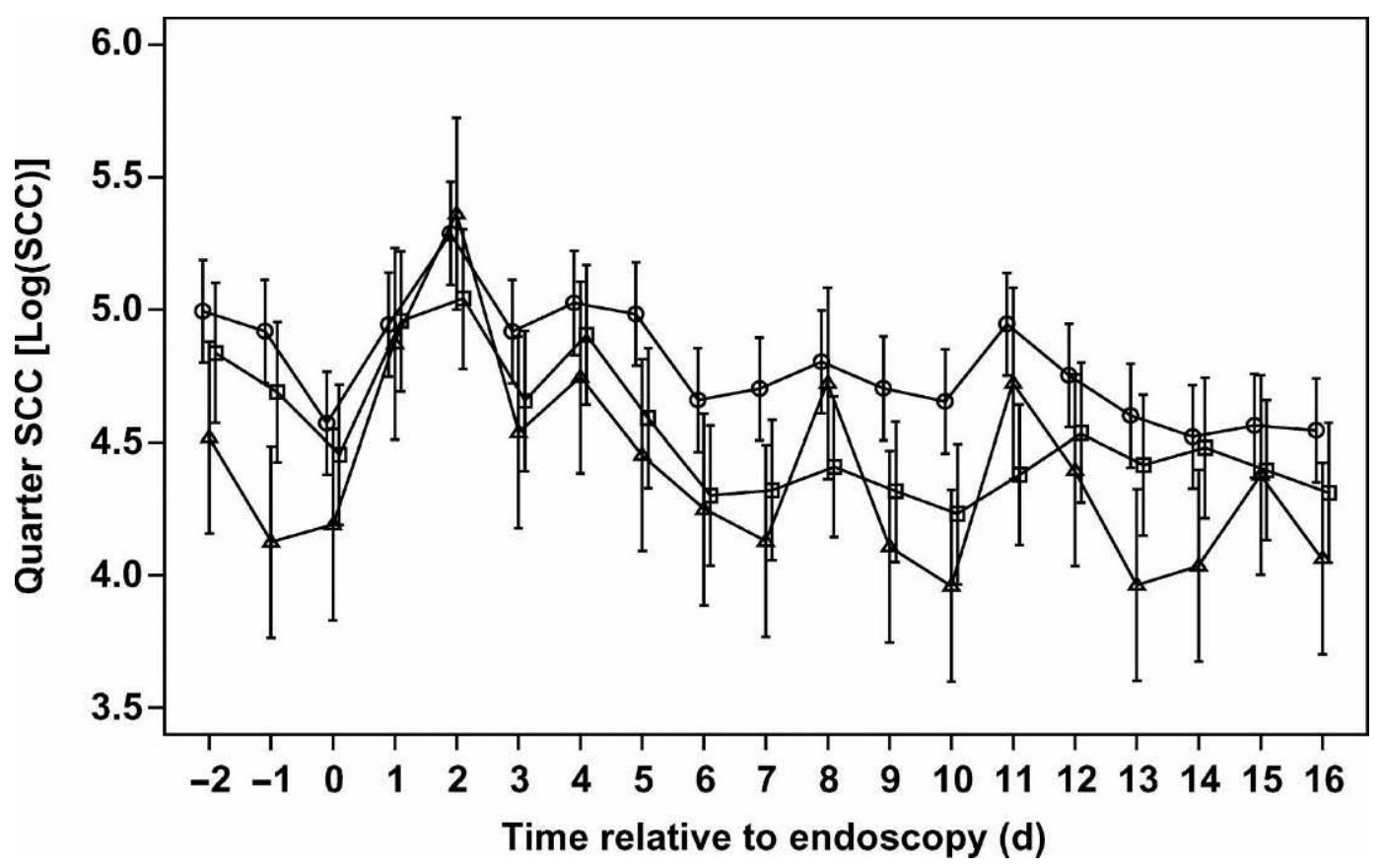

Figure 6. Quarter SCC $\left(\log _{10} / \mathrm{mL}\right.$, data are expressed as means \pm SEM) before and after endoscopic examination of the bovine mammary gland. All endoscopically treated quarters were visually explored and multiple tissue biopsy samples were collected. Day 0 represents the day of endoscopy; $\bigcirc=$ control quarters $(n=20), \triangle=$ endoscopy without antibiotic treatment $(n=4)$, and $\square=$ endoscopy + antibiotics $(n=8)$. 
gren, 1992; Persson et al., 1992,1993). Flushing of the mammary gland cistern for optimal visualization during the endoscopic procedure could be considered as one of the major disadvantages in the applicability of the technique for multiple sampling during experimentally induced mastitis because inflammatory mediators or bacterial substances are rapidly removed from the infected gland.

Although first- and second-lactation cows were used in the present study, no pronounced differences in penetrability of the teat canal could be observed between them (data not shown). The outside diameter of our endoscope equipped with a biopsy channel was only 3 $\mathrm{mm}$, which is comparable to other studies (Persson et al., 1992; Shakespeare, 1998; Hirsbrunner and Steiner, 1999). In most studies, biopsy samples were collected after endoscopic visualization through stab incision of the teat wall (Shakespeare, 1998; Hirsbrunner and Steiner, 1999), which allowed for use of an endoscope with a smaller outside diameter $(2.7 \mathrm{~mm}$; Shakespeare, 1998). The endoscopic technique described by Persson et al. (1992) was limited to direct endoscopic tissue biopsy collection in the area of the teat cistern because surgical separation of the teat cistern from the gland cistern had been performed (Persson and Åstrom, 1989; Persson et al., 1992).

In contrast to Shakespeare (1998), no general anesthesia was applied with the present endoscopic technique, which implies that cows in the present study could remain standing throughout the manipulation. Local anesthesia, a combination of epidural xylazine and morphine and intramammary procaine, provided enough anesthetic effect to work for at least $30 \mathrm{~min}$ in one quarter. The present endoscopic technique allowed full exploration of the teat and gland cistern without major interference from descending milk, which is comparable to the results of Shakespeare (1998). To collect biopsy samples, however, no stab incision was necessary for introduction of a tissue biopsy forceps.

In contrast to the prelevation of mammary tissue biopsies through invasive surgery (Knight et al., 1992; Farr et al., 1996) or at necropsy (Cifrian et al., 1994; Berry et al., 2003; Pfaffl et al., 2003), the endoscopic procedure yields much smaller amount of mammary tissue. The limited sample size did not, however, compromise the possible applications of the technique. Using an established epithelial cell culture model (Cifrian et al., 1994; Smits et al., 1996, 1998, 1999), a primary epithelial cell culture was obtained, originating from the small biopsy samples (data not shown). This epithelial cell culture could be used for PMN diapedesis research (Smits et al., 1996, 1998, 1999). Caution should be taken on the localization of tissue biopsy collection because variations in PMN diapedesis have been observed related to the type of epithelium used in cell culture (Smits et al., 1996). Diapedesis of PMN was greater across ductal cell monolayers than across secretory cell monolayers in response to complement component 5a. This might be explained by the difference in tightness of the junctional complexes between secretory and ductal cells (Smits et al., 1996). In the present study, it was not possible to collect biopsy samples from the secretory tissue in the upper part of the mammary gland. This limitation in tissue biopsy collection could be considered a major disadvantage of the present endoscopic technique.

Besides application of the collected tissue samples in primary epithelial cell culture and histological examination, we have shown that tissue sample size, although limited, was sufficient to perform mRNA analysis. In the present study, PCR analysis on the presence of GAPDH, a household gene, was performed. During experimentally induced mastitis, the expression of other genes (e.g., IGF-I, COX-2, iNOS, and PAF) in the bovine mammary tissue could be measured (Pfaffl et al., 2003; Schmitz et al., 2004). In our study, however, clinically healthy animals were used, and therefore, no other gene expressions were tested.

\section{CONCLUSIONS}

The described endoscopic procedure approaches the bovine mammary gland through the ductus papillaris. The endoscope, equipped with a biopsy channel, omitted the necessity for stab incisions to introduce sampling devices. Using the specific anesthesia protocol, endoscopy could be performed on standing animals. The technique is suitable for multiple sampling and repeated visualization of the teat and udder cistern of healthy, lactating cows without major complications. The collected biopsy samples, although limited in volume, could be used in primary epithelial cell culture, histological examination, and PCR analysis.

Using the present endoscopic technique, multiple tissue sampling during experimentally induced mastitis is possible. Moreover, follow-up of local epithelial changes in longitudinal studies also could be performed. This could offer new possibilities for studies throughout the lactation cycle and opportunities for multiple sampling during the early stages of experimentally induced mastitis.

\section{ACKNOWLEDGMENTS}

This study was supported by the Flemish Institute for the Encouragement of Research in the Industry (IWT-Grant No. 030784) and Fund for Scientific Research-Flanders (FWO-Vlaanderen, Grant Nos. 
3.1.208.04 and G.0050.06). The authors thank E. Vander Elstraeten, K. Demeyere, D. Vermaut, M. Verdonck, L. Standaert and L. De Bels for their excellent technical assistance.

\section{REFERENCES}

Berry, S. D. K., R. D. Howard, and R. M. Akers. 2003. Mammary localization and abundance of laminin, fibronectin, and collagen IV proteins in prepubertal heifers. J. Dairy Sci. 86:2864-2874.

Cifrian, E., A. J. Guidry, C. N. O’Brien, J. E. Keys, and W. W. Marquardt. 1994. Bovine mammary teat and ductual epithelial cell culture. Am. J. Vet. Res. 55:239-246.

Farr, V. C., K. Stelwagen, L. R. Cate, A. J. Molenaar, T. B. McFadden, and S. R. Davis. 1996. An improved method for the routine biopsy of bovine mammary tissue. J. Dairy Sci. 79:543-549.

George, L. W. 2003. Pain control in food animals. Pages 1-5 in Recent advances in anesthetic management of large domestic animals. E. P. Steffey, ed. International Veterinary Information Service, Ithaca, NY.

Hirsbrunner, G., R. Eicher, M. Meylan, and A. Steiner. 2001. Comparison of thelotomy and theloscopic triangulation for the treatment of distal teat obstructions in dairy cows-a retrospective study. Vet. Rec. 148:803-805.

Hirsbrunner, G., and A. Steiner. 1999. Use of a theloscopic triangulation technique for endoscopic treatment of teat obstructions in cows. J. Am. Vet. Med. Assoc. 214:1668-1671.

John, H., M. Hassig, D. Gobet, D. Sicher, and P. Jaeger. 1998. A new operative method to treat high teat stenosis in dairy cows. Br. J. Urol. 82:906-909.Knight, S. C., J. E. Hillerton, R. M. Teverson, and A. Winter. 1992. Biopsy of the bovine mammary gland. Br. Vet. J. 148:129-132.

Medl, M., K. Querengasser, C. Wagner, S. Paarmann, and P. Rusch. 1994. Clarification and treatment of teat stenosis using endoscopy. Tierarztl. Prax. 22:532-537.

Persson, K., and G. strom. 1989. Sampling of the bovine teat for studies of defence mechanisms and inflammatory reactions based on a surgical procedure separating the teat and udder cisterns. J. Vet. Med. B 36:527-531.

Persson, K., and C. Hallén Sandgren. 1992. A study of the development of endotoxin-induced inflammation in the bovine teat. Acta Vet. Scand. 33:283-295.

Persson, K., C. Hallén Sandgren, and H. Rodriguez-Martinez. 1992. Studies of endotoxin-induced neutrophil migration in bovine teat tissues, using indium-111-labeled neutrophils and biopsies. Am. J. Vet. Res. 53:2235-2240.
Persson, K., I. Larsson, and C. Hallén Sandgren. 1993. Effects of certain inflammatory mediators in bovine neutrophil migration in vivo and in vitro. Vet. Immunol. Immunopathol. 37:99-112.

Pfaffl, M. W., S. L. Wittmann, H. H. D. Meyer, and R. M. Bruckmaier. 2003. Gene expression of immunologically important factors in blood cells, milk cells, and mammary tissue of cows. J. Dairy Sci. 86:538-545.

Plath, A., R. Einspanier, W. D. Kraetzl, and D. Shams. 1997. Transforming growth factor alpha and beta-1 are differentially expressed in the bovine mammary gland during mammogenesis, galactopoiesis and involution. Livest. Prod. Sci. 50:41-51.

Querengasser, J., T. Geishauser, K. Querengasser, K. Fehlings, and R. Bruckmaier. 2002. Investigations of milk quality from teat with milk flow disorders. J. Dairy Sci. 85:2582-2588.

Roine, K. 1975. Observations on teat stenosis. Nord. Vet. Med. 27:107-111.

Schmitz, S., M. W. Pfaffl, H. H. D. Meyer, and R. M. Bruckmaier. 2004. Short-term changes of mRNA expression of various inflammatory factors and milk proteins in mammary tissue during LPS-induced mastitis. Domest. Anim. Endocrinol. 26:111-126.

Seeh, C., and R. Hospes. 1998. Experiences with a theloresectoscope compared with conventional teat endoscopy in diagnosis and therapy of covered teat lesions. Tierarztl. Prax. 26:110-118.

Shakespeare, A. S. 1998. Use of endoscopy to investigate abnormalities within the bovine udder and teat. Vet. Rec. 13:672-673.

Smits, E., C. Burvenich, A. J. Guidry, R. Heyneman, and A.-M. Massart-Leën. 1999. Diapedesis across mammary epithelium reduces phagocytosis and oxidative burst of bovine neutrophils. Vet. Immunol. Immunopathol. 68:169-176.

Smits, E., C. Burvenich, A. J. Guidry, and E. Roets. 1998. In vitro expression of adhesion receptors and diapedesis by polymorphonuclear neutrophils during experimentally induced Streptococcus uberis mastitis. Infect. Immun. 66:2529-2534.

Smits, E., E. Cifrian, A. J. Guidry, P. Rainard, C. Burvenich, and M. J. Paape. 1996. Cell culture system for studying bovine neutrophil diapedesis. J. Dairy Sci. 79:1353-1360.

Stocker, H., U. Battig, M. Duss, M. Zahner, M. Fluckiger, R. Eicher, and P. Rusch. 1989. Clarification of teat stenosis in cattle by ultrasound. Tierarztl. Prax. 17:251-256.

Tulleners, E., and A. Hamir. 1990. Effects of teat cistern mural biopsy and teatoscopy stab versus longitudinal incision with or without tube implant on incisional healing in lactating dairy cattle. Am. J. Vet. Res. 51:1257-1266.

Vangroenweghe, F., L. Duchateau, P. Boutet, P. Lekeux, P. Rainard, M. J. Paape, and C. Burvenich. 2005. Effect of carprofen treatment following experimentally induced Escherichia coli mastitis in primiparous cows. J. Dairy Sci. 88:2361-2376.

Vangroenweghe, F., L. Duchateau, and C. Burvenich. 2004. Moderate inflammatory reaction during experimental $E$. coli mastitis in primiparous cows. J. Dairy Sci. 87:886-895. 